\title{
A case of groans, moans and stones with malignant undertones: Endometrioid carcinoma-associated hypercalcemia
}

\author{
KOPPANY VISNYEI ${ }^{1}$, ARMIN SHAHROKNI ${ }^{4}$, SHAHRUKH HASHMI $^{3}$, \\ JEFFREY ORELL ${ }^{2}$ and DOROTHEA M.G. WILD ${ }^{1}$ \\ ${ }^{1}$ Department of Medicine and ${ }^{2}$ Center for Cancer Care, Griffin Hospital, Yale School of Medicine, \\ Derby, CT; ${ }^{3}$ James P. Wilmot Cancer Center, University of Rochester, NY; \\ ${ }^{4}$ Department of Geriatric Oncology at the University of California, Los Angeles, CA, USA
}

Received July 25, 2011; Accepted October 14, 2011

DOI: $10.3892 / \mathrm{ol} .2011 .475$

\begin{abstract}
Humoral hypercalcemia of malignancy is frequently observed in patients with solid tumors. However, few instances have been described involving patients with gynecological malignancies. We report a case of endometrioid carcinoma of the uterine corpus in a patient who initially presented with hypercalcemia. The elevated calcium levels were found to be the result of an increased serum concentration of parathyroid hormone-related peptide (PTHrP). PTHrP is commonly secreted by malignant cells and suppresses PTH. This case demonstrates that endometrial cancer should be considered in the differential diagnosis of patients presenting with symptomatic or asymptomatic hypercalcemia.
\end{abstract}

\section{Introduction}

Hypercalcemia occurs in a considerable subset of individuals diagnosed with malignancy, which is the most common cause of hypercalcemia in the inpatient setting (1). While elevated levels of calcium in these patients may prompt clinicians to initiate a work-up of malignancy, diagnostic efforts generally focus only on certain tumor types. The most common malignancies associated with hypercalcemia are breast and lung cancer and multiple myeloma. Among the tumors of the gynecological tract, certain ovarian tumors, mostly dysgerminoma, have been shown to cause humoral hypercalcemia of malignancy (7). However, uterine malignancies have been rarely described as the cause of elevated calcium levels (2-6).

Hypercalcemia in cancer patients is primarily due to increased bone resorption and release of calcium from bone. Three major mechanisms by which this occurs have been

Correspondence to: Dr Koppany Visnyei, Department of Medicine, Griffin Hospital, 130 Division Street, Derby, CT 06401, USA

E-mail: koppanyvisnyei@gmail.com

Key words: endometrial tumor, parathyroid hormone-related protein, uterine cancer identified: i) the presence of osteolytic metastases with local release of cytokines; ii) the secretion of 1,25-dihydroxyvitamin D (calcitriol); or iii) the production of parathyroid hormone-related protein (PTHrP) by the tumor cells (8). The physiological and pathophysiological role of PTHrP in the female reproductive system has been investigated. PTHrP has been found to be expressed in the normal endometrium with a cyclical expression pattern during the menstrual cycle (9). This peptide has also been shown to affect myometrium contractility and to dilate placental blood vessels. Additionally, certain data also indicate that it plays a role in endometrial proliferation (10-12). Besides its diverse physiological functions in the female reproductive system, there is limited data on PTHrP expression in the cancer endometrial tissue. The aim of the present case report was to emphasize the clinical significance of elevated PTHrP as a paraneoplastic phenomenon in endometrial malignancies. The study described here was approved by the ethics committee of Griffin Hospital, Derby, CT, USA. Consent for publication was obtained from the patient's next of kin.

\section{Case Report}

A nulliparous 81-year old female presented to the Griffin Hospital in Derby, CT, USA, with weakness, repetitive falls and episodes of confusion. The patient also complained of vaginal bleeding of a few months duration. The physical examination was normal. Blood analysis revealed an elevated serum calcium level of $11.9 \mathrm{mg} / \mathrm{dl}$ (normal, $8.5-10.5 \mathrm{mg} / \mathrm{dl}$ ), and decreased albumin of $3.3 \mathrm{~g} / \mathrm{dl}$ (normal, 3.5-5.0 g/dl). The creatinine level was $1.1 \mathrm{mg} / \mathrm{dl}$ (normal, $0.5-1.0 \mathrm{mg} / \mathrm{dl}$ ) and that of blood urea nitrogen (BUN) was $21 \mathrm{mg} / \mathrm{dl}$ (normal, 7-17 mg/dl). The complete blood count (CBC) for the patient did not reveal any irregularities. The thyroid panel revealed a normal TSH of $1.83 \mu \mathrm{U} / \mathrm{ml}$ (normal, 0.27-4.2 $\mu \mathrm{U} / \mathrm{ml}$ ), and normal T4, total T3 and free T4 levels $(7.17 \mu \mathrm{g} / \mathrm{dl}, 70.9 \mathrm{ng} / \mathrm{dl}$ and $1.1 \mathrm{ng} / \mathrm{dl}$, respectively). The patient's parathyroid hormone (PTH) level was decreased at $<2.5 \mathrm{pg} / \mathrm{ml}$ (normal, 14-72 pg/ $\mathrm{ml}$ ) and the PTHrP was elevated at $7 \mathrm{pmol} / \mathrm{l}$ (normal, $<2$ $\mathrm{pm} / \mathrm{l})$. The patient had normal 25-hydroxy-vitamin (D2+D3) levels of $34 \mathrm{ng} / \mathrm{ml}$ (normal, $25-80 \mathrm{ng} / \mathrm{ml}$ ) and low 1,25-dihydroxyvitamin D levels of $15 \mathrm{pg} / \mathrm{ml}$ (normal, $18-78 \mathrm{pg} / \mathrm{ml}$ ). 

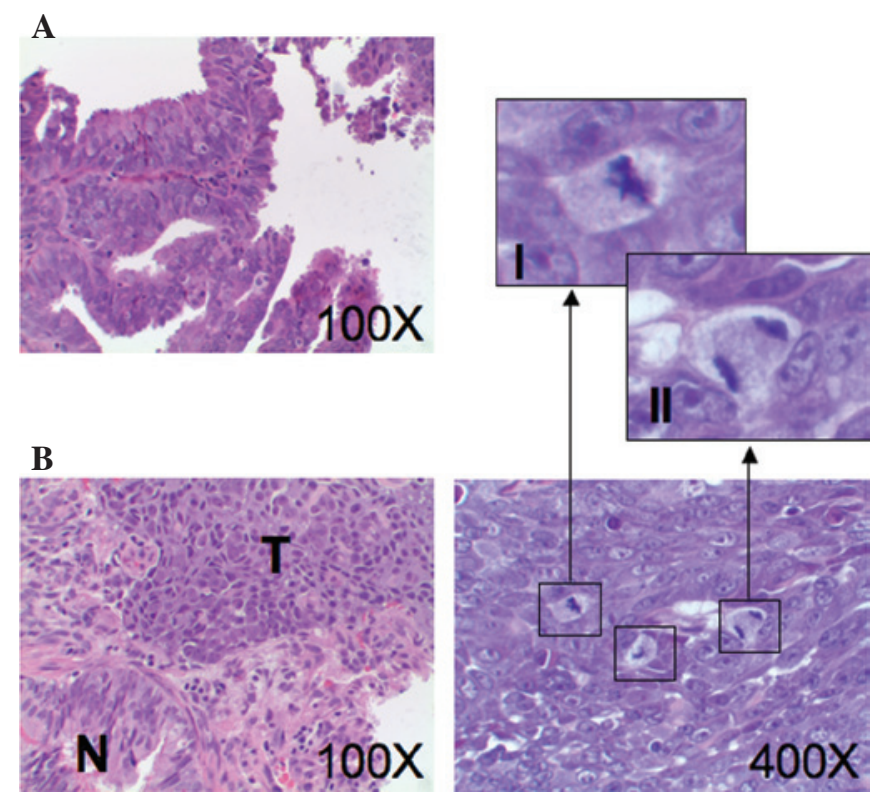

Figure 1. Histopathological analysis of the biopsy revealing endometrioid carcinoma. (A) Normal endometrium. (B) Malignant tissue (T) infiltrating normal stroma $(\mathrm{N})$. Note the high frequency of the mitotic figures within the tumor mass. (See insets for high-power field images; H\&E staining on paraffin-embedded sections).

Thyroglobulin antibody and thyroperoxidase antibody titers were negative. A skeletal survey revealed no signs of multiple myeloma, and the chest $\mathrm{x}$-ray and mammogram were normal.

The patient underwent MRI imaging, which revealed a uterine mass indicative of malignancy. Dilation and curettage were performed. Histopathological studies of the collected material confirmed the diagnosis of endometrioid carcinoma (Fig. 1). Due to advanced age and multiple comorbidities, the patient and her family decided against tumor resection and other aggressive treatment. The hypercalcemia has been treated successfully with pamidronate.

\section{Discussion}

In the present case report, we describe a clinical case with endometrioid carcinoma, hypercalcemia and increased PTHrP production. This combination is highly indicative of malignancy-associated PTHrP-induced humoral hypercalcemia, as other potential causes of the elevated serum calcium levels were excluded. Work-up of the patient ruled out exogenous calcium supplementation, hypervitaminosis D and primary and secondary hyperparathyroidism. The work-up did not reveal any clinical evidence of malignant myeloma, mammary gland tumor, lung tumor, bone metastases or sarcoidosis. These results and the elevated PTHrP combined with the secondary PTH suppression indicated that the tumor caused the hypercalcemia noted in this patient.

Notably, the patient had normal 25-hydroxyvitamin levels with low 1,25-dihydroxyvitamin D levels. This, in conjunction with normal kidney function, indicated a low 1- $\alpha$-hydroxylase activity. This pattern is often observed in humoral hypercalcemia of malignancy due to chronically elevated serum calcium levels $(13,14)$. In contrast, in primary hyperpara- thyroidism we expect to find elevated PTH levels and, as a direct physiological response, increased 1,25-dihydroxyvitamin D levels.

Normalization of the hypercalcemic state following tumor removal may have provided us with additional proof for the presence of a true paraneoplastic syndrome. However, tumor treatment was declined in this case.

In an extensive review including 5260 patients with gynecological malignancies, Jaishuen et al (15) identified 35 patients who had endometrial carcinoma as well as elevated calcium levels. Due to the retrospective nature of this study, the exact cause of hypercalcemia could not be determined in each individual case. Therefore, it is unknown how many of the 35 patients genuinely exhibited humoral hypercalcemia of malignancy. Nevertheless, the incidence of paraneoplastic hypercalcemia in this type of gynecological malignancy may be higher than expected and reported in other studies.

An extensive search of the literature at the time of submission identified only five case reports describing uterine malignancies with paraneoplastic PTHrP production. Among these cases were clear cell endometrial carcinoma (16), papillary serous carcinoma (4) and one single reported case of endometrioid carcinoma (5).

In conclusion, although hypercalcemia is a relatively rare presentation in uterine cancer, this case emphasizes the need to maintain a broad differential diagnosis in the work-up of patients with hypercalcemia.

\section{Acknowledgements}

We would like to thank Dr Stephanie Wain at the Department of Pathology at Griffin hospital for the histopathological images.

\section{References}

1. Stewart AF: Clinical practice. Hypercalcemia associated with cancer. N Engl J Med 352: 373-379, 2005.

2. Hiller N, Sonnenblick M and Hershko C: Paraneoplastic hypercalcemia in endometrial carcinoma. Oncology 46: 45-48, 1989.

3. Buller R, Taylor K, Burg AC, Berman ML and DiSaia PJ: Paraneoplastic hypercalcemia associated with adenosquamous carcinoma of the endometrium. Gynecol Oncol 40: 95-98, 1991.

4. Sachmechi I, Kalra J, Molho L and Chawla K: Paraneoplastic hypercalcemia associated with uterine papillary serous carcinoma. Gynecol Oncol 58: 378-82, 1995.

5. Kinugasa Y, Morishige K, Kamiura S, Tsukamoto Y and Saji F: Parathyroid hormone-related protein-secreting uterine endometrioid adenocarcinoma. Jpn J Clin Oncol 36: 113-115, 2006.

6. Ashour AA, Verschraegen CF, Kudelka AP and Kavanagh JJ: Paraneoplastic syndromes of gynecologic neoplasms. J Clin Oncol 15: 1272-1282, 1997.

7. Savvari P, Peitsidis P, Alevizaki M, Dimopoulos MA, Antsaklis A and Papadimitriou CA: Paraneoplastic humorally mediated hypercalcemia induced by parathyroid hormonerelated protein in gynecologic malignancies: a systematic review. Onkologie 32: 517-23, 2009.

8. Broadus AE, Mangin M, Ikeda K, Insogna KL, Weir EC, Burtis WJ, et al: Humoral hypercalcemia of cancer. Identification of a novel parathyroid hormone-like peptide. N Engl J Med 319: 556-563, 1988.

9. Hoshi S, Morimoto T, Saito H, Ichizuka K, Matsuoka R, Yanaihara A, et al: PTHrP and PTH/PTHrP receptor expressions in human endometrium. Endocr J 48: 219-225, 2001.

10. Mok LL, Nickols GA, Thompson JC and Cooper CW: Parathyroid hormone as a smooth muscle relaxant. Endocr Rev 10: 420-436, 1989. 
11. Williams ED, Leaver DD, Danks JA, Moseley JM and Martin TJ: Effect of parathyroid hormone-related protein (PTHrP) on the contractility of the myometrium and localization of PTHrP in the uterus of pregnant rats. J Reprod Fertil 102: 209-214 1994.

12. Heffner LJ, Kumari M and Benoit LA: Secretion of the vasoactive peptides, endothelin, and parathyroid hormone-related peptide, by decidual explants from pregnancies complicated by intrauterine growth restriction. J Soc Gynecol Investig 6: 273-277, 1999.

13. Schilling T, Pecherstorfer M, Blind E, Leidig G, Ziegler R and Raue F: Parathyroid hormone-related protein (PTHrP) does not regulate 1,25-dihydroxyvitamin $\mathrm{D}$ serum levels in hypercalcemia of malignancy. J Clin Endocrinol Metab 76: 801-803, 1993.
14. Syed MA, Horwitz MJ, Tedesco MB, Garcia-Ocana A, Wisniewski SR and Stewart AF: Parathyroid hormone-related protein-(1-36) stimulates renal tubular calcium reabsorption in normal human volunteers: implications for the pathogenesis of humoral hypercalcemia of malignancy. J Clin Endocrinol Metab 86: 1525-1531, 2001.

15. Jaishuen A, Jimenez C, Sirisabya N, Li Y, Zheng H, Hu W, et al: Poor survival outcome with moderate and severe hypercalcemia in gynecologic malignancy patients. Int J Gynecol Cancer 19: 178-185, 2009.

16. Richey DS and Welch BJ: Concurrent primary hyperparathyroidism and humoral hypercalcemia of malignancy in a patient with clear cell endometrial cancer. South Med J 101: 1266-1268, 2008. 